\title{
SWINE EFFLUENT TREATMENT USING ANAEROBIC DIGESTION AT DIFFERENT LOADING RATES
}

\author{
ANDRÉ C. DO AMARAL ${ }^{1}$, AIRTON KUNZ ${ }^{2}$, RICARDO L. R. STEINMETZ ${ }^{3}$, \\ FÁBIO CANTELLI ${ }^{4}$, LUCAS A. SCUSSIATO ${ }^{5}$, KARIN C. JUSTI ${ }^{6}$
}

\begin{abstract}
The industrial swine production is characterized by generation of significant effluent amounts that require treatment. The most adopted practices by Brazilian swine farmers have been wastewater storage in lagoons and its subsequent use as a biofertilizer. Nutrient accumulation in soil and water creates the need for an effective management of these residues. The anaerobic digestion process is an important alternative and low-cost treatment for organic matter reduction. However, its efficiency is limited by the digester capacity of solid degradation, especially at low hydraulic retention times. Thus, the present study aimed to verify the behavior of an upflow anaerobic digester by increasing the organic loading rate. This was accomplished in three stages using, as a parameter, volatile solids at $0.5 ; 1.0$ and $1.5 \mathrm{kgVS} \mathrm{m}^{-3} \mathrm{~d}^{-1}$, respectively. This digester model proved to be quite robust and effective in swine manure treatment, achieving high efficiency of volatile solid removal at all stages of the study (stage 1: $61.38 \%$; stage 2: $55.18 \%$; and stage 3: $43.18 \%$ ). Biogas production was directly related to the increasing organic load, reaching $0.14,0.85$, and 0.86 $\mathrm{Nm}^{3} \mathrm{kgVS}^{-1}$ add., respectively, with no significant difference $(\mathrm{p}<0.05)$ of biogas methane concentration among the studied stages (73.7, 75.0, and 77.9\%).
\end{abstract}

KEYWORDS: hydraulic retention time, biogas production, animal wastewater.

\section{TRATAMENTO DE EFLUENTE DA SUINOCULTURA UTILIZANDO PROGRESSÃO DE CARGA ORGÂNICA EM BIODIGESTOR ANAERÓBIO DE FLUXO ASCENDENTE}

RESUMO: A suinocultura industrial tem como característica a geração de significativas quantidades de efluente que necessitam de tratamento. O processo de biodigestão anaeróbia surge como uma alternativa importante, de baixo custo para o tratamento e eficiente na redução da matéria orgânica das águas residuárias da suinocultura. Porém os processos anaeróbios têm sua eficiência limitada, entre muitos aspectos, pela concentração de sólidos voláteis no biodigestor e sua capacidade de mineralização da matéria orgânica em função do tempo de retenção hidráulica. Diante disso, o presente estudo teve por objetivo verificar o comportamento de um biodigestor anaeróbio de fluxo ascendente, alimentado com dejetos de suínos, mediante progressão de carga de sólidos voláteis. O estudo foi realizado em três etapas, utilizando-se como parâmetro de sólidos voláteis a 0,$5 ; 1,0$ e $1,5 \mathrm{kgSV} \mathrm{m}^{-3} \mathrm{~d}^{-1}$, respectivamente. Este modelo de biodigestor mostrou ser bastante eficaz e robusto no tratamento de efluentes da suinocultura, atingindo boa eficiência na remoção de sólidos voláteis em todas as etapas do trabalho (etapa 1: 61,38\%, etapa 2: 55,18\% e etapa 3: 43,18\%). A produção de biogás teve relação direta com o aumento da carga orgânica, atingindo 0,$14 ; 0,85$ e $0,86 \mathrm{Nm}^{3} \mathrm{kgSV}_{\text {adic., }}$ respectivamente, não havendo diferença significativa $(\mathrm{p}<0,05)$ na porcentagem de metano no biogás entre elas $(73,7 ; 75,0$ e 77,9\%).

PALAVRAS-CHAVE: tempo de retenção hidráulica, produção de biogás, resíduos animais.

\footnotetext{
${ }^{1}$ Químico, mestrando em química, UNICENTRO, Guarapuava - PR, andrec.doamaral@gmail.com

${ }^{2}$ Químico Industrial, Pesquisador, EMBRAPA Suínos e Aves, Concórdia - SC, Professor no Programa de Pós-Graduação em Engenharia Agrícola, UNIOESTE, Cascavel - PR, airton.kunz@embrapa.br

${ }^{3}$ Químico Industrial, mestre em química, analista A, Embrapa Suínos e Aves, Concórdia - SC, ricardo.steinmetz@embrapa.br

${ }^{4}$ Eng$^{\circ}$ Ambiental, Especialista, Solução Engenharia e Meio Ambiente, Concórdia - SC, solucao@solucao-ema.com.br

${ }^{5}$ Graduando em Engenharia Ambiental, UNC, Concórdia - SC, bolsista de iniciação científica, lucas.a.scussiato@gmail.com

${ }^{6}$ Química, Doutora em Química, Profa. Adjunta, Departamento de Pós-Graduação em Química, UNICENTRO, Guarapuava - PR.

Recebido pelo Conselho Editorial em: 4-4-2013

Aprovado pelo Conselho Editorial em:19-12-2013
} 


\section{INTRODUCTION}

The swine industry is characterized by intensive pig production, what generates substantial effluent amounts in small areas. This residue has high concentrations of organic matter, nutrients, and metals with major pollution potential (STEINMETZ et al., 2009). Therefore, new management strategies are necessary when compared with those currently adopted, which are effluent storage and agricultural use, especially in areas of high livestock density (KUNZ et al., 2009a).

Several alternatives are available for the treatment of effluents with high concentrations of organic material. Among them, the anaerobic digestion is a very competitive technology (LEE et al., 2009) with great acceptance by users due to: low costs of implementation, operation, and maintenance; possibility to use the produced biogas as a source of electricity and heat; and integration into the carbon market. The generated effluents have readily available nutrients that may be used as a biofertilizer or, in the absence of available areas for its application, be subjected to additional treatment (APPELS et al., 2008; JINGURA \& MATENGAIFA, 2009).

The central point of an anaerobic treatment system is the used digester model, with constant search for low cost alternatives and projects adapted to the substrate type. The development of upflow anaerobic digesters combines numerous advantages over conventional processes, especially concerning area requirements, implementation simplification, maintenance, and operation, which enable their use for a wide variety of wastewaters (CAMPOS et al., 2006; DUDA \& OLIVEIRA, 2011).

As process parameters, volatile solids (VS) and chemical oxygen demand (COD) are widely used to evaluate the performance of anaerobic digesters, as both are associated and allow inferences to the effluent biodegradable fraction (CHERNICHARO, 2007).

The performance of anaerobic digesters increases when operated in the mesophilic range (20$40^{\circ} \mathrm{C}$ ), in comparison with the psychrophilic $\left(4-15^{\circ} \mathrm{C}\right)$, due to higher biological activity under those conditions (ABBASI et al., 2012). Using laboratory-scale digesters (14 L) and wastes of finishing phase swine, SOUZA et al. (2005) achieved higher biogas production, that is, $4.11 \mathrm{~L}_{\mathrm{N}} \cdot \mathrm{d}^{-1}$ at $35^{\circ} \mathrm{C}$, while at $25^{\circ} \mathrm{C}$, it was only $0.34 \mathrm{~L}_{\mathrm{N}} \cdot \mathrm{d}^{-1}$.

Another related factor is the organic load which the digester can support; recommended values of livestock waste range from 1 to $3.5 \mathrm{kgSV} \mathrm{m}^{-3} \mathrm{~d}^{-1}$ (KASHYAP et al., 2003). Sudden changes in organic loads may also change the digester capacity to promote degradation and, also, the volume and quality of the generated biogas (CHAE et al., 2008).

In reactors of continuous loading, the organic load applied to the digester is linked to the hydraulic retention time (HRT). Changes in HRT affect the availability period among substrates and anaerobic microorganisms, what is a crucial factor in the attempt to maximize the methanogenic activity (KIM et al., 2012).

Therefore, the objective of this study was to determine the capacity of an upflow anaerobic digester, loaded with swine effluent and operated at mesophilic temperatures, to support different loads of volatile solids. To this end, we evaluated the capacity of organic matter degradation and production and quality of the generated biogas after HRT decrease in the digester.

\section{MATERIAL AND METHODS}

\section{Experimental design}

The experiments were conducted at the experimental unit of Embrapa Swine and Poultry, in Concórdia, Santa Catarina State, Brazil.

The swine effluent used in this study came from two farrow-to-finish pig farms with capacity for 3,800 animals. The effluent was stored in a gutter collection system; subsequently, it was sent by gravity to the swine Manure Treatment Plant (SMTP), passing through a flow damping box with adjustable gates and a $2 \mathrm{~mm}$ rotating sieve for coarse solid retention, and then homogenized in the 
equalization tank (ET) (KUNZ et al., 2006). In this study, the effluent was directly repressed from ET according to the required flow. A BioKöhler ${ }^{\circledR}$ digester (Figure 1) was used, which was produced in fiberglass, with an upflow system and working volume of $10 \mathrm{~m}^{3}$. The internal temperature (36 $\pm 2{ }^{\circ} \mathrm{C}$ ) was maintained by using a serpentine system for water recirculation throughout the experimental period. Biomass was agitated by recirculating the effluent itself for 2 minutes every day to prevent clogging.

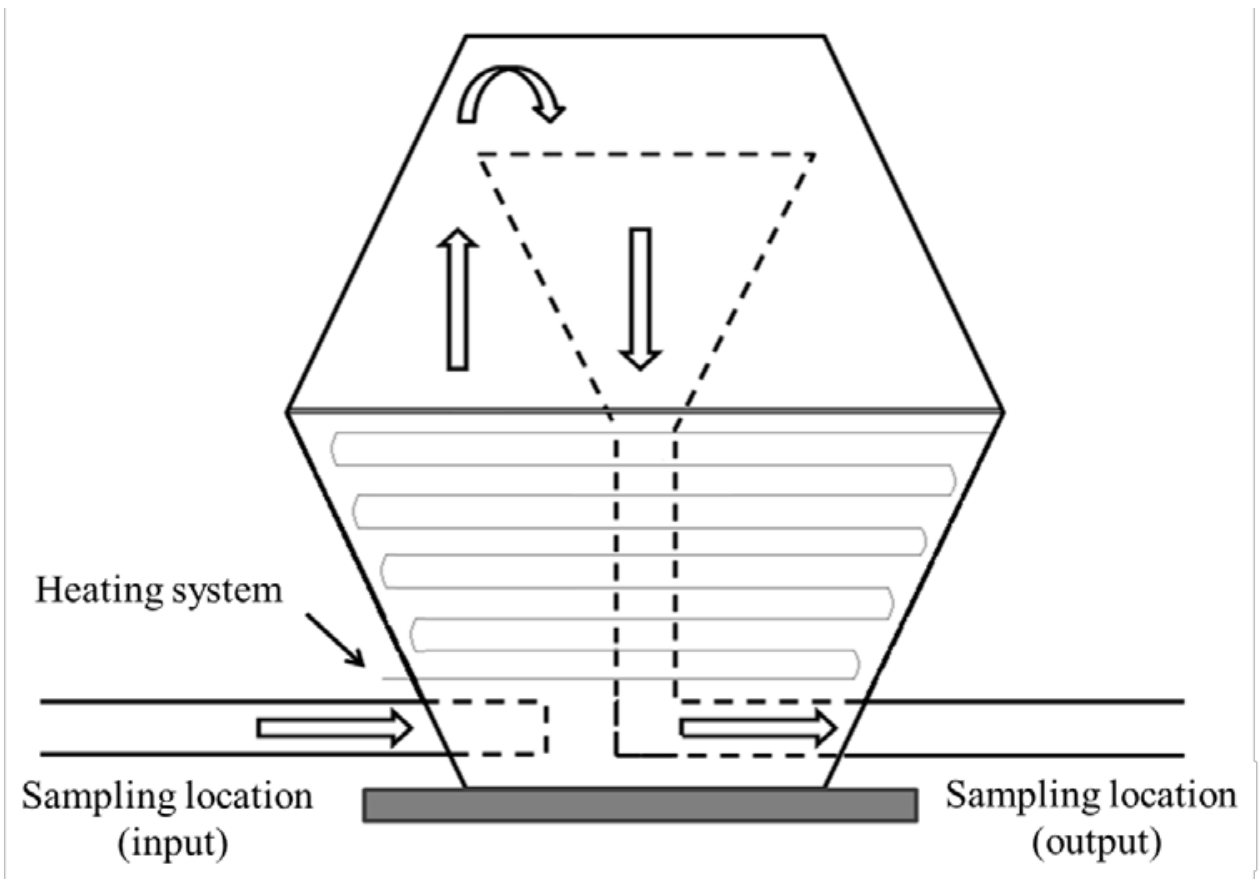

FIGURE 1. Schematic diagram of BioKöhler ${ }^{\circledR}$ upflow digester with sampling locations and heating system.

\section{Loading progression in volatile solids}

Loading progression in the digester was performed in three stages as shown in Table 1.

TABLE 1. Description of the studied stages with respective loading flow rates, HRT and estimated loading of volatile solids (VS), and chemical oxygen demand (COD).

\begin{tabular}{ccccc}
\hline \multirow{2}{*}{ Stage } & \multirow{2}{*}{ Flow $\left(\mathrm{m}^{3} \mathrm{~d}^{-1}\right)$} & \multirow{2}{*}{$\mathrm{HRT}^{\mathrm{a}}(\mathrm{d})$} & \multicolumn{2}{c}{ Estimated Loading } \\
\cline { 3 - 5 }$\left(\mathrm{kgSV} \mathrm{m}^{-3} \mathrm{~d}^{-1}\right)$ & $\mathrm{kg} \mathrm{O}_{2} \mathrm{~m}^{-3} \mathrm{~d}^{-1}$ \\
\hline 1 & $0.56 \pm 0.01$ & $17.86 \pm 0.10$ & $0.45 \pm 0.02$ & $1.16 \pm 0.01$ \\
3 & $1.32 \pm 0.01$ & $7.57 \pm 0.06$ & $1.00 \pm 0.01$ & $2.74 \pm 0.02$ \\
\hline
\end{tabular}

Mean \pm standard deviation; (a) HRT - hydraulic retention time.

Digester loading was intermittently performed, due to the minimum work flow of the repression system, via a submerged pump in ET controlled by a timer. Considering the preestablished daily flow for each stage, the loading pump was activated for 3.2 minutes every two hours during stage 1; 3.2 minutes every 1 hour during stage 2; and 4.8 minutes every 1 hour during stage 3 .

\section{Sampling}

Samples were collected at two locations (input and output), representing the swine effluent before and after the anaerobic treatment (Figure 1), and then stored at $4{ }^{\circ} \mathrm{C}$ until analysis.

Sample collections were carried out in different periods from the agitation system operation. Analytical determinations 


\section{Chemical oxygen demand (COD)}

The COD analyses were performed according to the procedure described by APHA (2012), which is based on the sample acid digestion in the presence of potassium dichromate in a closed reflux system, held in a digester at $150^{\circ} \mathrm{C}$ for $2 \mathrm{~h}$. After sample cooling, absorbance reading was carried out in a spectrophotometer at $620 \mathrm{~nm}$.

\section{Total solids (TS) and volatile solids (VS)}

Analyses were performed according to APHA (2012). Samples were dried at $105^{\circ} \mathrm{C}$, until constant weight, for determination of the TS level, and then muffle furnace calcined at $550{ }^{\circ} \mathrm{C}$ for $1 \mathrm{~h}$ for determination of the fixed solids (FS). The VS content was obtained by the difference between TS and FS.

\section{Biogas production}

Biogas production was determined by a meter, type THERMAL, model FT2 (CONTECH $\left.{ }^{\circledR}\right)$.

\section{Biogas composition}

Determination of $\mathrm{CO}_{2}$ was performed by adapting the Orsat method (KUNZ \& OLIVEIRA, 2009): $\mathrm{NaOH}$ solution reacts with $\mathrm{CO}_{2}$, absorbing it in solution as carbonate and bicarbonate. The difference between initial and final volumes was used to estimate $\mathrm{CO}_{2}$ and methane concentration. The $\mathrm{H}_{2} \mathrm{~S}$ was determined by the method of methylene blue, reacting with ferric sulfide and dimethyl-p-phenylenediamine in acid to produce methylene blue. After the reaction, ammonium phosphate was added to eliminate the color produced by excess ferric chloride. Concentration was then determined by colorimetric comparison (APHA, 2012).

\section{Statistical analysis}

Statistical analyses were performed using GraphPad Prism software, version 3.02. The mean confidence interval of the experimental data was calculated by Equation (1).

$$
\mu \pm t\left(\frac{s}{\sqrt{n}}\right)
$$

where,

$$
\begin{aligned}
& \mu \text { - mean value; } \\
& \mathrm{s} \text { - standard deviation; } \\
& \mathrm{n} \text { - number of replications, and } \\
& \mathrm{t} \text { - corresponding value to t-Student distribution (95\% confidence level). }
\end{aligned}
$$

A significance test among means was performed at $5 \%$ confidence level $(\mathrm{P}<0.05)$; the $n$ value varied for each studied item.

\section{RESULTS AND DISCUSSION}

The swine effluent used in this study showed great concentration variability (Figure 2). This behavior is inherent to the concerned production process due to factors that directly influence the effluent composition. VANOTTI \& SZOGI (2008) and RODRIGUES et al. (2010) attributed these variations to water consumption by pigs, waste in facilities, animal number fluctuations in farms, and, mainly, the pig growing phase. The presence of a larger number of pre-slaughter animals reduces the effluent dilution. Also, nutritional aspects and manure storage time in gutters directly influence swine effluent concentration and biodegradability (KUNZ et al., 2009 b; JUNIOR et al., 2010; SUZUKI et al., 2010).

These factors reflect what happens in confined animal production systems (CAPS), having direct effects on strategies for effluent management and treatment; therefore, they must be understood and systemically treated. Efficiency of the anaerobic digestion process, which is the subject of this study, is discussed as follows. 


\section{COD removal}

As shown in Table 1, a gradual decrease occurred in the effluent HRT in the digester during stages $1 ; 2$ and 3, resulting in the efficiency reduction of COD removal in the system.

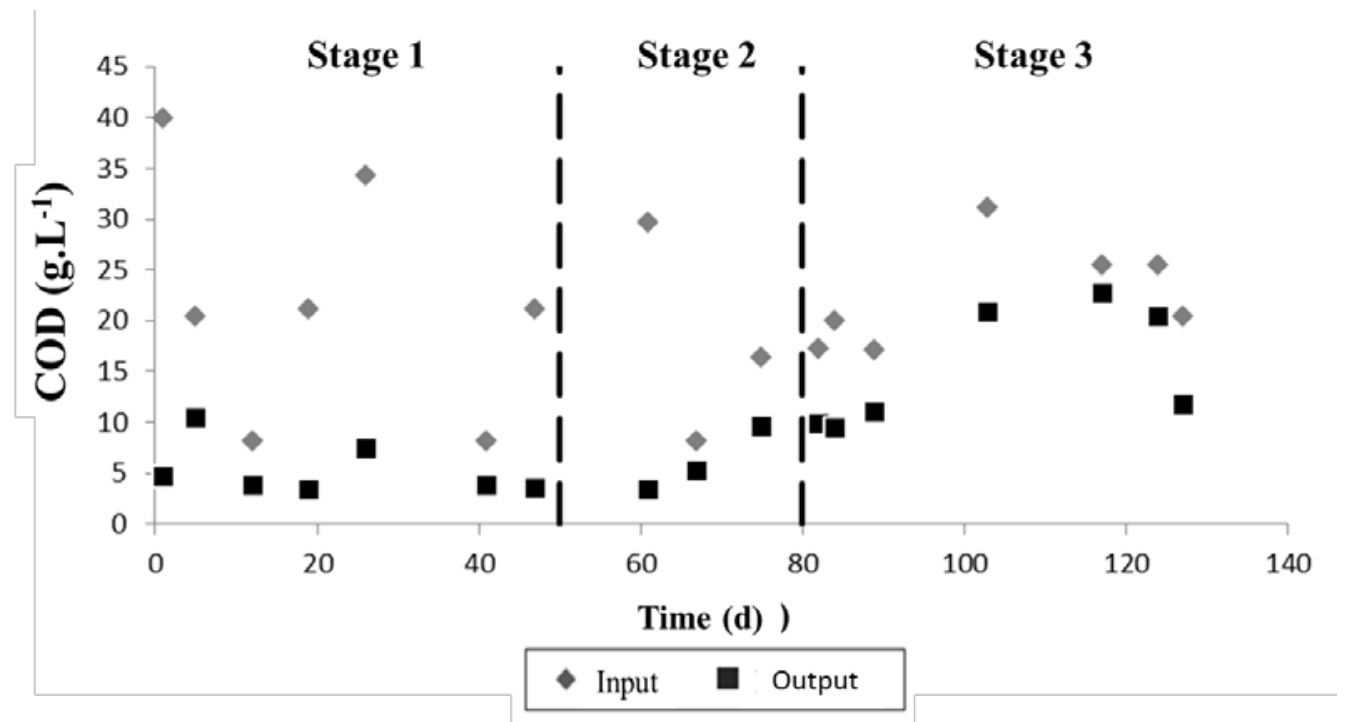

FIGURE 2. Chemical oxygen demand (COD) in the digester input and output during the experimental stages.

Mean output values of COD and confidence intervals for stages 1,2 , and 3 were: 2.69 g.L $\mathrm{L}^{-1} \pm$ 0.07; 3.16 g. $L^{-1} \pm 0.13$; and 5.89 g. $L^{-1} \pm 0.15$, respectively. Significant differences between stages 1 and $3(\mathrm{p}=0.0017)$, and 2 and $3(\mathrm{p}=0.0392)$ indicate that the HRT decrease reduced the capacity of organic matter removal, which was $75.85 \%$ (stage 1), 66.36\% (stage 2), and 32.31\% (stage 3 ). The HRT decrease has significant impacts on the early stages of anaerobic digestion, and is directly related to biodegradation and substrate availability (DEUBLEIN \& STEINHAUSER, 2008).

The use of shorter HRT in stages 2 and 3 may have limited the initial anaerobic digestion stages (ELEFSINIOTIS \& WAREHAM, 2007). Hydrolysis is often the limiting stage of the process, as hydrolytic bacteria, via extracellular enzymes, break down complex organic compounds, such as starch, pectin, hemicelluloses, lipids, and proteins, into simple ones, such as amino acids and volatile fatty acids (EVANS \& FURLONG, 2011). Acidogenesis is the metabolizing process, by acidogenic bacteria, of sugars, amino acids, peptides, long-chain fatty acids, and low molecular weight molecules to form short-chain fatty acids, $\mathrm{CO}_{2}, \mathrm{H}_{2}, \mathrm{NH}_{3}, \mathrm{SO}_{4}{ }^{-2}$, and alcohols (METCALF \& EDDY, 2003).

The necessary time for further organic matter degradation depends on the digester model and material to be digested; lower rates of substrate degradation result in longer cell duplication periods (by the limiting substrate), also requiring longer HRT (WELLINGER, 1999). Our results indicate that digestion of swine effluents in the studied reactor requires HRT of 7.5 days, or more, to reach satisfactory levels of organic matter removal (> 60\%).

The anaerobic digestion process comprises several species of microorganisms that may be divided into two groups, acidogenic bacteria and methanogenic archaea, which require different conditions for cell growth and maintenance. Some studies report that the implementation of these stages in separate reactors (two stages) increases the substrate degradation capacity, as one shall be operated under optimum conditions for acidogenesis, while the other, for methanogenesis (UENO et al., 2001; HORI et al., 2006).

\section{Volatile solid removal and biogas production capacity}


Loading of volatile solids in the digester (Figure 3) showed instability due to changes in its concentration, especially in stage 3 , which reasons have already been discussed; this also resulted in greater variability in the reactor output load.



FIGURE 3. Load of volatile solids (VS) in the digester input, and removal rates, during the experimental stages.

Considering the three studied stages, there was a significant difference only for VS removal between stages 1 and $3(\mathrm{p}=0.03)$. The results shown in Table 2 indicate that VS load conditions for biogas production were better during stages 2 and 3, while stage 1 promoted higher organic matter degradation, that is, greater capacity to stabilize the swine effluent. OLIVEIRA \& HIGARASHI (2006) also described higher biogas production according to the added VS when the digester operated under lower HRT and $35^{\circ} \mathrm{C}$.

TABLE 2. Mean digester input load, removal rates, and VS removal percentage, with the respective confidence intervals, and maximum biogas generation capacity during the experimental stages.

\begin{tabular}{ccccc}
\hline Stage & $\begin{array}{c}\text { Mean input load } \\
\left(\mathrm{kgVS} \mathrm{m}^{-3} \mathrm{day}^{-1}\right)\end{array}$ & $\begin{array}{c}\text { Mean removed load } \\
\left(\mathrm{kgVS} \mathrm{m}^{-3} \mathrm{day}^{-1}\right)\end{array}$ & VS removal $(\%)$ & $\begin{array}{c}\text { MBGC* }^{*} \\
\left(\mathrm{Nm}^{3} \text { of biogas Kg VS }\right. \\
\text { add })\end{array}$
\end{tabular}

*Maximum biogas generation capacity.

During stage 1 , the studied reactor showed better mineralization capacity of the organic matter present in the swine effluent since the VS removal was greater than $60 \%$; however, maximum biogas generation capacity (MBGC) was lower in this stage. VIVAN et al. (2010) achieved production of $0.33 \mathrm{Nm}^{3} \mathrm{kgVS}^{-1}$ add and VS removal of $34.63 \%$ using a covered lagoon digester model, with no heating system, HRT of 45 days, and loading of $0.55 \mathrm{kgVS} \mathrm{m}^{-3} \mathrm{~d}^{-1}$.

The MBGC results, obtained during stages 2 and 3, are approximately six times higher than that achieved for stage 1, but still lower than that found by KUNZ \& ENCARNACAO (2007), who found $1.43 \mathrm{~m}^{3} \mathrm{kgVS}^{-1}$ add for an upflow anaerobic sludge blanket (UASB) reactor, loaded with swine manure pre-treated by flocculation and solid separation. As UASB reactors operate at low HRT, high concentrations of suspended solids may affect the hydrolysis stage, impairing biogas production. Therefore, when this type of digester is used for the treatment of swine effluents, there is a need for a preliminary treatment aiming at removing suspended solids (GARCÍA et al., 2008). 
Greater availability of organic load to anaerobic microorganisms (stages 2 and 3) promoted higher MBGC as there was an increase in the substrate/microorganism ratio. This effect was also observed by PEREZ et al. (1999) as the increase in organic load (from 5 to $25 \mathrm{~kg} \mathrm{COD} \mathrm{m}^{-3} \mathrm{~d}^{-1}$ ) enhanced the biogas production capacity from 0.05 to $0.55 \mathrm{Nm}^{3} \mathrm{kgCOD}_{\text {add }}$. AQUINO \& CHERNICARO (2005) suggest that anaerobic microorganisms in the digester are underused under low organic loads, what results in the MBGC decrease.

An alternative for increasing biogas production is to raise the volumetric organic load per concentration of organic matter, without changing the HRT. This was observed by KAPARAJU et al. (2010), who added maize straw and vinasse to the swine manure, in ratios of 5, 10, and 15\%, to increase the organic load $\left(9.7 ; 12.4\right.$ and 17.1 gCOD L $\left.^{-1} \mathrm{~d}^{-1}\right)$ without changing the HRT of 48 days, resulting in higher methane productions (100.0; 127.2 and $154.8 \mathrm{~mL} \mathrm{CH}_{4} \mathrm{gCOD}^{-1}$ ).

When digesters are operated at low hydraulic retention times, the use of a previous hydrolysis stage is recommended to avoid system overload (LI et al., 2010).

\section{Quality of produced biogas}

Figure 4 shows monitoring of the biogas quality produced during the study.

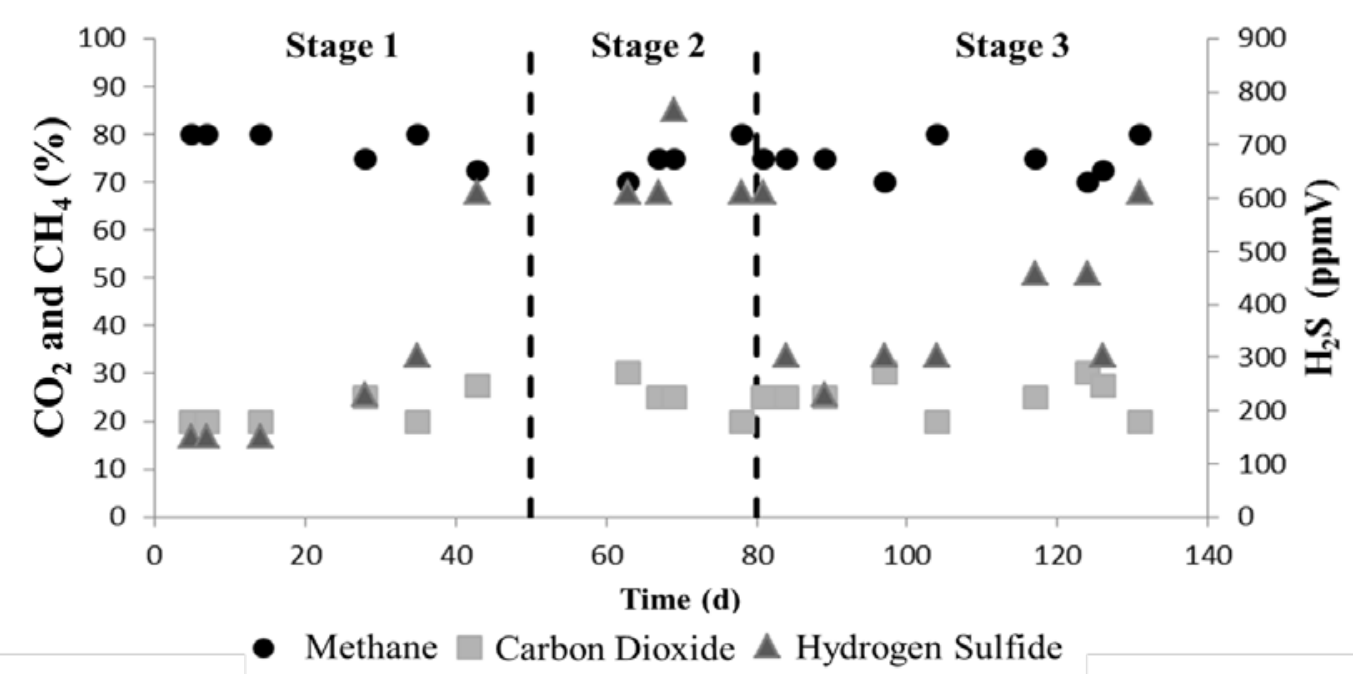

FIGURE 4. Characterization of the produced biogas; methane $\left(\mathrm{CH}_{4}\right)$, carbon dioxide $\left(\mathrm{CO}_{2}\right)$, and hydrogen sulfide $\left(\mathrm{H}_{2} \mathrm{~S}\right)$ during the experimental stages.

Methane percentage during the three stages were: $77.92 \pm 0.09 \%$ (stage 1 ); $75.00 \pm 0.14 \%$ (stage 2); and $74.72 \pm 0.08 \%$ (stage 3 ), with no significant differences among results.

Maximum capacity of methane production during the stages was: $0.112 \pm 0.07 \mathrm{Nm}^{3} \mathrm{CH}_{4} \mathrm{~kg}^{-1}$ $\mathrm{VS}_{\text {add }}$ (stage 1); $0.636 \pm 0.11 \mathrm{Nm}^{3} \mathrm{CH}_{4} \mathrm{~kg}^{-1} \mathrm{VS}_{\text {add }}$ (stage 2); and $0.649 \pm 0.06 \mathrm{Nm}^{3} \mathrm{CH}_{4} \mathrm{~kg}^{-1} \mathrm{VS}_{\text {add }}$ (stage 3). Results from stages 2 and 3 were considered high when compared with the described in the literature (BONMATI et al., 2001; CHAE et al., 2008; AHN et al., 2009). Using swine manure as substrate for anaerobic digestion, and operating reactors at mesophilic conditions, BONMATI et al. (2001) achieved production of $0.347 \mathrm{Nm}^{3} \mathrm{CH}_{4} \mathrm{~kg}^{-1} \mathrm{VS}_{\text {add, }} \mathrm{CHAE}$ et al. (2008), of $0.437 \mathrm{Nm}^{3} \mathrm{CH}_{4} \mathrm{~kg}^{-1} \mathrm{VS}_{\text {add }}$, and AHN et al. (2009), of $0.337 \mathrm{Nm}^{3} \mathrm{CH}_{4} \mathrm{~kg}^{-1} \mathrm{VS}_{\text {add }}$. The HRT decrease, along with increasing VS loading in the digester, promoted an increment in methane production, so this may be applied as a strategy to enhance production when it is the main objective of the anaerobic digestion use.

Mean concentrations found for hydrogen sulfide $\left(\mathrm{H}_{2} \mathrm{~S}\right)$ during the studied stages were: 266.83 $\pm 4.82 \mathrm{ppmV}$ (stage 1); $648.75 \pm 2.64 \mathrm{ppmV}$ (stage 2); and $398 \pm 3.05 \mathrm{ppmV}$ (stage 3). There were 
significant differences of concentrations between stages 1 and $2(\mathrm{p}=0.0041)$, and 2 and 3 $(\mathrm{p}=0.0075)$. There was no significant difference between stages 1 and 3 .

During the anaerobic process, $\mathrm{H}_{2} \mathrm{~S}$ formation occurs primarily due to degradation of sulfurcontaining proteins (e.g. methionine and cysteine) or by reduction of the medium sulfate. The $\mathrm{H}_{2} \mathrm{~S}$, when in the gas phase, comes in contact with sulfur-oxidizing bacteria, which oxidize $\mathrm{H}_{2} \mathrm{~S}$ in the presence of trace amounts of oxygen. This conversion may occur directly in the gas chamber, precipitating elemental sulfur in the digester inner walls (NAMGUNG et al., 2012). Variations in the biogas $\mathrm{H}_{2} \mathrm{~S}$ concentration, as already discussed, are related to changes in the swine effluent composition, generating different $\mathrm{H}_{2} \mathrm{~S}$ amounts and, also, to the availability of different oxygen trace amounts in the medium.

\section{CONCLUSIONS}

The increase of organic loading in the digester presented a high maximum biogas generation capacity (MBGC) per added volatile solid. This effect is enhanced by the HRT decrease, as MBGC was six times greater when the volumetric organic load was increased from 0.436 to $1.853 \mathrm{kgVS} \mathrm{m}^{-3} \mathrm{~d}^{-1}$ with decreasing HRT from 17.86 to 5.32 days.

This is highly significant for the proposed system when the objective is to produce biogas. However, the COD decrease had an opposite effect to the MBGC, that is, the digester mineralization capacity was reduced according to lower HRT, what affects effluent quality. To minimize this effect, a pre-hydrolysis stage may be added to the system, which may contribute to increased substrate availability to methane-producing microorganisms, greater MBGC, and COD reduction of the final effluent.

\section{ACKNOWLEDGMENTS}

This study was financially supported by CAPES and Itaipu. The authors thank the International Center for Renewable Energy (CIER-Biogas) for providing the reactor used in this study.

\section{REFERENCES}

ABBASI, T.; TAUSEEF, S. M.; ABBASI, S.A. Anaerobic digestion for global warming control and energy generation - An overview. Renewable and Sustainable Energy Reviews, New York, v.15, n.5, p. 3228-3242, 2012.

AHN, H.K.; SMITH, M.C.; KONDRAD, S.L.; WHITE, J.W. Evaluation of biogas production potential by dry anaerobic digestion of switchgrass - animal manure mixtures. Applied Biochemistry and Biotechnology, Clifton, v.160, p. 965-975, 2009.

APHA - American Public Health Association. Standard methods for examination of water and wastewater. 22 ${ }^{\text {th }}$. ed. Washington: APHA, 2012.

APPELS, L.; BAEYENS, J.; DEGREVE, J.; DEWIL, R. Principles and potential of the anaerobic digestion of waste-activated sludge. Progress in Energy and Combustion Science, Oxford, v. 34, p.755-581, 2008.

AQUINO, S. F.; CHERNICHARO, C. A. L. Acúmulo de ácidos graxos voláteis (AGVs) em reatores anaeróbios sob estresse: causas e estratégias de controle. Engenharia Sanitaria Ambiental, Rio de Janeiro, v. 10, p. 152-161, 2005.

BONMATI, A.; FLOTATS, X.; MATEU, L.; CAMPOS, E. Study of thermal hydrolysis as a pretreatment to mesophilic anaerobic digestion of pig slurry. Water Science and Technology, Oxford, v.44, n.4, p.109-116, 2001. 
CHAE, K.J.; JANG, A.; YIM, S.K.; KIM, I.S. The effects of digestion temperature and temperature shock on the biogas yields from the mesophilic anaerobic digestion of swine manure. Bioresource Technology, v.99, p-1-6, 2008.

CHERNICHARO, C. A. L. Reatores anaeróbios. 2.ed. Belo Horizonte: UFMG, 2007.

DEUBLEIN D.; STEINHAUSER, A. Biogas from waste and renewable resources - an introduction. Weinheim: Wiley-VCH, 2008.

DUDA, R. M.; OLIVEIRA, R. A. Tratamento de águas residuárias de suinocultura em reator UASB e filtro anaeróbio em série seguidos de filtro biológico percolador. Engenharia Sanitaria Ambiental, Rio de Janeiro, v. 16, p.91-100, 2011.

ELEFSINIOTIS, P.; WAREHAM, D.G. Utilization patterns of volatile fatty acids in the denitrification reaction. Enzyme and Microbial Technology, New York, v. 41, n. 1-2, p. 92-97, 2007.

EVANS, G.M.; FURLONG, J.C. Environmental biotechnology: theory and application. 2.ed. West Sussex: John Wiley \& Sons, 2011. 293 p.

GARCÍA, H.; RICO, C.; GARCÍA, P. A.; RICO, J. L. Flocculants effects in biomass retention in a UASB reactor treating dairy manure. Bioresource Technology, Essex, v, 99, p. 6028-6036, 2008.

HORI, T.; HARUTA, S.; UENO, Y.; ISHII, M.; IGARASHI, Y. Dynamic transition of a methanogenic population in response to the concentration of volatile fatty acids in a thermophilic anaerobic digester. Applied Environmental Microbiology, v.72, p.1623-1630, 2006.

JINGURA, R.M.; MATENGAIFA, R, Optimization of biogas production by anaerobic digestion for sustainable energy development in Zimbabwe. Renewable Sustainable Energy Revews, New York, v.13, p. 1116-1120, 2009.

JUNIOR, M. A. O.; ORRICO, A. C. A.; JÚNIOR, J. L. Avaliação de parâmetros da biodigestão anaeróbia de suínos alimentados com dietas a base de milho e sorgo. Engenharia Agrícola, Jaboticabal, v. 30, n.4, p.600-607, 2010.

KAPARAJU, P.; SERRANO, M.; ANGELIDAKI, I. Optimization of biogas production from wheat straw stillage in UASB reactor. Applied Energy, London, v.87, n.12, p.3779-3783, 2010.

KASHYAP, D. R.; DADHICH, K. S.; SHARMA; S. K. Biomethanation under psychrophilic conditions. Bioresource Technology, Essex, v.87, p.147-153, 2003.

KIM W.; SHIN S. G.; CHO, K.; LEE, C.; HWANG, S. Performance of methanogenic reactors in temperature phased two-stage anaerobic digestion of swine wastewater. Journal of Bioscience and Bioengineering, Osaka, v.114, n.6, p.635- 639, 2012.

KUNZ, A.; ENCARNACAO, R. Tratamento de dejetos de animais. In: GEBBLER, L. ; PALHARES, J.C.P.. (Org.). Gestão ambiental na agropecuária. Brasília: Embrapa Informação Tecnológica, 2007. p. 167-191.

KUNZ, A.; MIELE, M.; STEINMETZ, R. L. R. Advanced swine manure treament end utization in Brazil. Bioresource Technology, Essex, v.100, n.22, p.5485-5489, 2009 (a).

KUNZ, A.; OLIVEIRA, L. Sistema e método de análise química qualitativa e quantitativa de gás. P.I. 0706174-9 (Patente). 2009.

KUNZ, A.; SCHIERHOLT, G.; MENOZZO, G.F.; BORTOLI, M.; RAMME, M.; COSTA, R. Estação de tratamento de dejetos de suínos (ETDS) como alternativa na redução do impacto ambiental da suinocultura. Concórdia: Embrapa Suínos e Aves, 2006. p. 1-6. (Comunicado Técnico, 452). 
KUNZ, A.; STEINMETZ.R. L. R.; RAMME, M. A.; COLDEBELLA, A. Effect of storage time on swine manure solid separation efficiency by screening. Bioresource Technology, Essex, v.100, n.5 p.1815-1818, 2009 (b).

LEE, M.; HIDAKA, T.; HAGIWARA, W.; TSUNO, H. Comparative performance and microbial diversity of hyperthermophiclic and thermophilic co-digestion of kitchen garbage and excess sludge.Bioresource Technology, Essex, v.100, p. 578-585, 2009.

LI, P.; WANG, Y.; WANG, Y.; LIU, K.; TONG, L. Bacterial community structure and diversity during establishment of an anaerobic bioreactor to treat swine wastewater. Water Science \& Technology, Kidlington, v. 61, n. 1, p 243-252. 2010.

METCALF \& EDDY. Wastewater engineering: treatment and reuse. $4^{\text {th }}$ ed. New York: Ed. McGraw Hill, 2003.

NAMGUNG, H. K.; AHN H.; SONG, J. Development of a two-phase bioreactor for the biological removal of hydrogen sulfide from biogas. Energy Procedia, Neltherlands, v. 14, p.1143-1148, 2012.

OLIVEIRA, P.A.V.; HIGARASHI, M.M. Geração e utilização de biogás em unidades de produção de suínos. Concórdia: Embrapa Suínos e Aves, 2006. (Documentos, 115).

PÉREZ, M.; ROMERO, L. I.; SALES, D. Anaerobic thermophilic fluidized bed treatment of industrial wastewater: effect of F:M relationship. Chemosphere, Oxford, v. 38, p. 3443-3461, 1999.

RODRIGUES, L. S.; SILVA, J. I.; ZOCRATO, M. C. O.; PAPA, D. N.; SPERLING, M. V.; OLIVEIRA, P. R. Avaliação de desempenho de reator UASB no tratamento de águas residuárias de suinocultura. Revista Brasileira de Engenharia Agrícola e Ambiental, Campina Grande, v. 14, n.1, p.94-100, 2010.

SOUZA, C F.; LUCAS JÚNIOR; FERREIRA, J. de; WILLIAMS, P. M. Biodigestão anaeróbia de dejetos de suínos sob efeito de três temperaturas e dois níveis de agitação do substrato:

considerações sobre a partida. Engenharia Agrícola, Jaboticabal, v.25, n.2, p.530-539, 2005.

STEINMESTZ, R.L.R.; KUNZ, A.; DRESSLER, V.L.; FLORES, E.M.M.; MARTINS, A.F. Study of metal distribution in raw and screened swine manure. Clean - Soil Air Water Journal, Amsterdam, v.37, n.3, p.239-244, 2009

SUZUKI, K.; WAKI, M.; YASUDA, T.; FUKUMOTO, Y.; KURODA, K.; SAKAI, T.; SUZUKI, N.; SUZUKI, R.; MATSUBA, K. Distributions of phosphorus, copper and zinc in activated sludge treatment process f swine wastewater. Bioresource Technology, Essex, v.101, p. 9399-9404, 2010.

UENO, Y.; HARUTA, S.; ISHII, M.; IGARASHI, Y. Changes in product formation and bacterial community by dilution rate on carbohydrate fermentation by methanogenic microflora in continuous flow stirred tank reactor. Applied Microbiology and Biotechnology, Berlin, v. 57, p. 6573, 2001.

VANOTTI, M. B.; SZOGI, A. A. Water quality improvements of wastewater from confined animal feeding operations after advanced treatment. Journal of Environmental Quality, Madison, v.37, p.86-96, 2008.

VIVAN M.; KUNZ, A.; STOLBERG, J.; PERDOMO, C.; TECHIO, V. H. Eficiência da interação biodigestor e lagoas de estabilização na remoção de poluentes em dejetos de suínos. Revista Brasileira de Engenharia Agrícola e Ambiental, Campina Grande, v.15, n.3, p. 320-325, 2010.

WELLINGER, A. Process design of agricultural digesters. Elggerstrasse: Nova Energie GmbH, 1999. 